\title{
KWh Meter Smart Card Model Token For Electrical Energy Monitoring
}

\author{
Riki Ruli A. Siregar ${ }^{1 *}$, Hengki Sikumbang ${ }^{1}$, Iriansyah BM. Sangadji ${ }^{1}$, Indrianto $^{1}$ \\ ${ }^{1}$ Informatics Engineering, Sekolah Tinggi Teknik PLN Cengkareng West Jakarta. Indonesia
}

\begin{abstract}
This research Producer Electric meter Appliance model base on smart card kWh (kilo Watt hour). The card power meter Is use to calculate the prepaid electricity meter using the 20-digit voucher number as a charging medium. Utilizing a smart card, the token number in the prepaid electricity meter can help reduce the error rate when entering the token number, the model destination is created. Hardware design and with apps to detect how much energy is used to store basic data to help view history of usage. Using smart cards and microcontrollers in apps that come from a usage history in the Pulse usage category will help users know their usage in efficient, normal, and wasteful categories. The results of this research is a meter model with credit card for charging pulses, and data processing applications as devices that can be used for various electricity consumption. The information system is used as a model validation with pulse input that provides information about the use of electrical energy and as a determinant to save the time and time required to make optimal energy
\end{abstract}

\section{Introduction}

Prepaid Electricity is one form of technological development of PLN which is used to regulate the use of household electrical energy through electricity meter that has been integrated directly with the central database in PLN [1]. This innovation is expected to make people feel comfortable in electric energy payment transactions, because people no longer need to come to the counter-office of PLN area to make electricity payment but by using electric pulses people can easily fill their own amount of electrical energy they want to use. Although this innovation is very helpful to the people in the process of purchasing electricity transactions, but some people are still difficult in using pre-paid electricity meter. Of the 20 digit digit of electric vouchers, people sometimes find it difficult to include digit vouchers into the prepaid meter. In addition, if there is an error in input token number then must re-enter the token number, also from the purchase of token numbers that must be purchased to the counter sales of electric pulses or via ATM each will charge the electric pulse [1]. The model of monitoring the use and saving of electrical energy with wireless sensor network technology [2] [3] [4], in this study aims to monitor the use of electrical energy and austerity solutions. Model made in the form of the design and operation of automation of power tools by placing the spread of several sensors that act as

\footnotetext{
*Corresponding author: riki.ruli@sttpln.ac.id
} 
sensors and monitor the use of electrical appliances operate and can be controlled remotely by implementing wireless sensor and actuator network (WSAN) technology with scheduling method node [5] [2] [6]. This technology serves to monitor the electricity consumption and electrical energy savings [7] [8] [9]. Smart meter design for monitoring and identification of electrical energy consumption in the household sector using backpropagation neural network [10]. Analog and digital kWH meter models do not have features that can monitor load currents, identify electronic equipment equipment and record actual electrical energy usage covering the time of use of electronics equipment and display costs to be paid by consumers [11]. Develop an IoT-based utility system (Internet of things) that is useful for efficiently powering electricity and gradually reducing electricity bills using the fuzzy method [12] [13]. The fuzzy method is used to control the device being used so that the user is always alert to the power consumption and reduces the current charge [4] [12]. Several studies have done by charging pulses through cellular transmission. The $\mathrm{kWh}$ meter model used is equipped with SMS-based communication module, the system can communicate with the users via SMS, to check and fill quota $\mathrm{kWh}$ meter, and provide warning (reminder) if the remaining quota on $\mathrm{kWh}$ meter is near the level of discharged [14].

\section{System Design}

The Proposed System designed to replace the old system in this design is as follows:

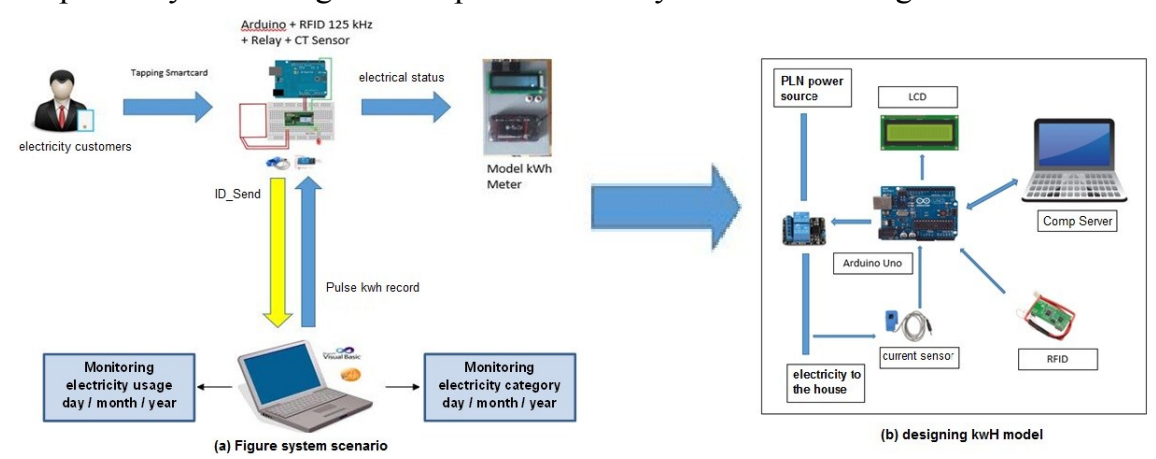

Fig 1. Design of Electric Kwh meter model

The method used for system validation as a way of categorizing step of use by testing on the $2200 \mathrm{VA} \mathrm{kWh}$ meter model, with the following test scenarios:
a. Electrical Power
: $2200 \mathrm{VA}$
b. Average usage per month $\pm: 380 \mathrm{kWh}$
c. $\quad 380 \mathrm{kWh} /$ month $=380,000 \mathrm{Wh} / 2.592 .000 \mathrm{sec}=0.14667$
d. To simplify the calculation rounded to $0.15 \mathrm{Wh} / \mathrm{sec}$,

Membership Function Electricity Usage per second (X)

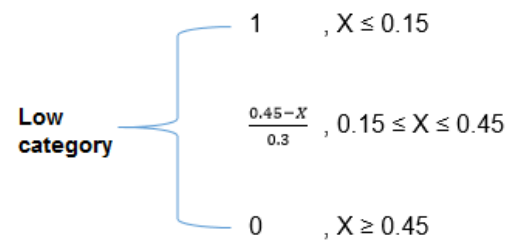



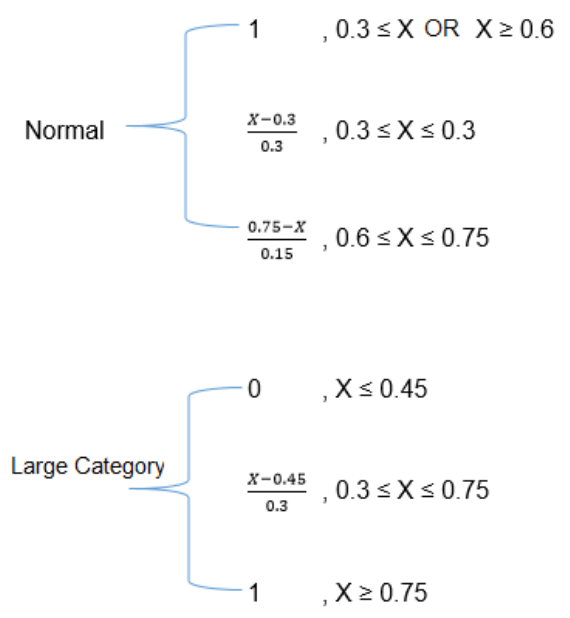

Scenario Membership Function Total Electricity Usage (Y)

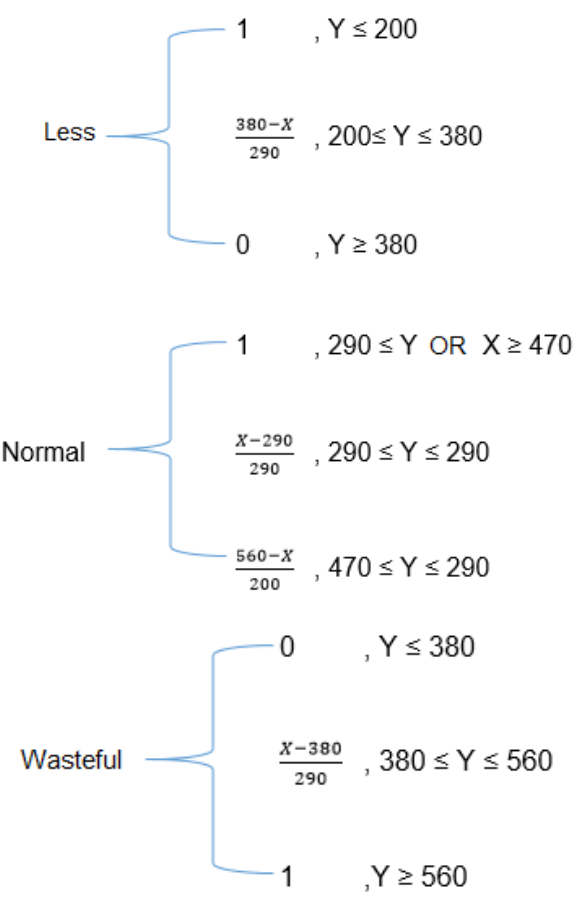

Rule used:

$\mathrm{R} 1$, if $\mathrm{X}=$ low dan $\mathrm{Y}=$ Less then $\mathrm{Z}=$ Less

$\mathrm{R} 2$, if $\mathrm{X}=$ low dan $\mathrm{Y}=$ Normal then $\mathrm{Z}=$ Normal

$R 3$, if $X=$ low dan $Y=$ Large then $Z=$ Wasteful

$\mathrm{R} 4$, if $\mathrm{X}=$ normal dan $\mathrm{Y}=$ Less then $\mathrm{Z}=$ Normal

$\mathrm{R} 5$, if $\mathrm{X}=$ normal dan $\mathrm{Y}=$ normal then $\mathrm{Z}=$ Normal

$\mathrm{R} 6$, if $\mathrm{X}=$ normal dan $\mathrm{Y}=$ Large then $\mathrm{Z}=$ Wasteful

$\mathrm{R} 7$, if $\mathrm{X}=$ large dan $\mathrm{Y}=$ Less then $\mathrm{Z}=$ Wasteful

$R 8$, if $X=$ large dan $Y=$ normal then $Z=$ Wasteful

$\mathrm{R}$, if $\mathrm{X}=$ large dan $\mathrm{Y}=$ Large then $\mathrm{Z}=$ Wasteful 


\section{Results}

The kwH model uses hardware in a microcontroller that moves as a brain or controller in activating each component of the model. The process of tapping with a smart card then automatically the information contained in the smart card will be read by the application of the number of pulses, after the pulse is read in the application then the customer can make electrical energy. Once the electricity in the instrument hardware is active then the application can automatically read how much current is used by the instrument and converted into electrical energy.

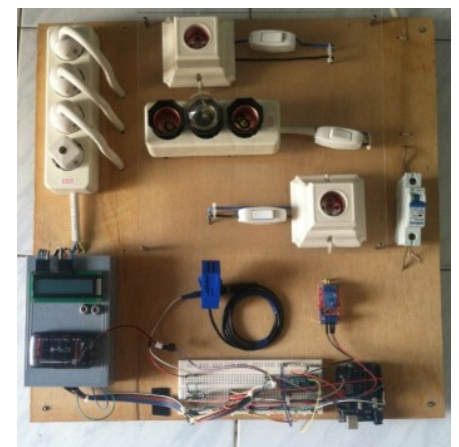

Fig 2. Prepaid kwh meter model

Users have more permissions that allow the electrical energy shown in Figure 3, viewing electricity consumption per day, month and year can also see efficient, normal or wasteful category of electricity usage every day, month and year.

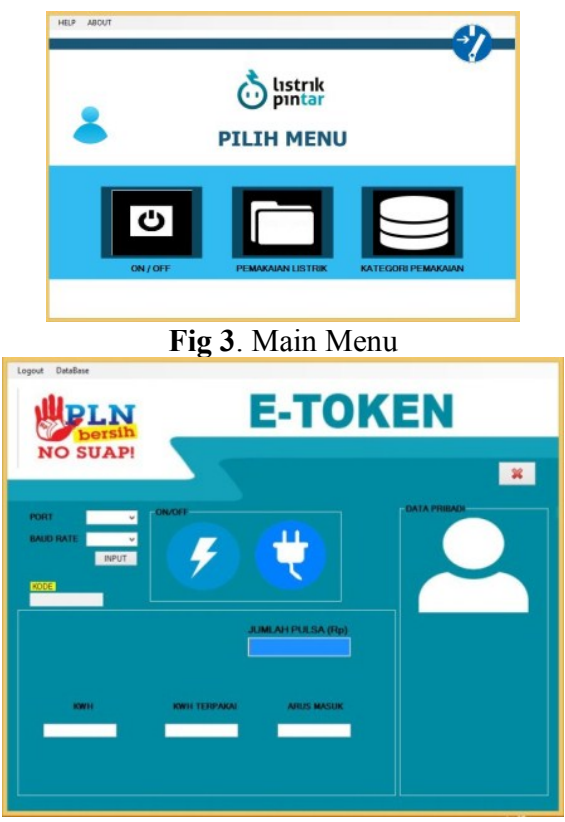

Fig 4. Controlled Application kWh Meter 
Figure 4, is the menu that will set the ON / OFF power set on the hardware. In this menu can see a large amount of energy and see the amount of energy found from the application. This menu is accessible to a power user.

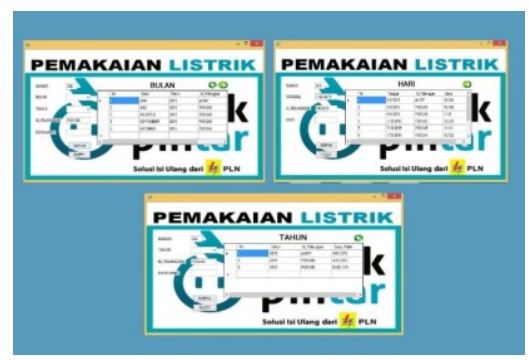

Fig 5. History of electricity usage

Figure 5, is a menu to see the amount of electricity consumption every day, month and year. Automatically each time shows 24.00 hours then the application will issue a command that automatically saves energy consumption into the database on the server.

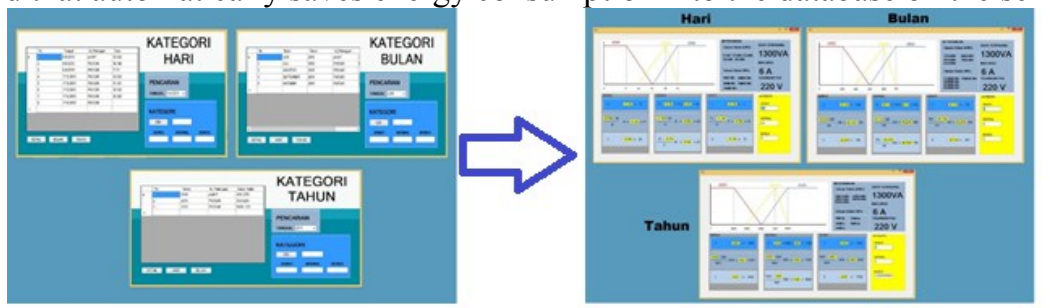

Fig 6. The category of electricity used

Picture. 6 is an application menu that shows detailed calculations used for the determination of electricity usage categories every day, month and year. It will also display graphs as a constraint to determine the efficient, normal or wasteful use of electricity.

\section{Conclucion}

The process of inserting electrical pulses into the power meter by using a smart card can be done by connecting from the hardware and software design so that when the user conducts the lead the smartcard pulse will automatically read into the application. So the process of determining the electricity consumption in a household can be done using a CT sensor is a sensor that will read the flow. So from the resulting current can be calculated how much Energy is used. And the determination of the category of electricity consumption can be done by utilizing the choice of categories in the application. The results obtained can show the values obtained for testing on decision support systems

\section{Acknowledgements}

We would like to thank the Ministry of Research and Technology of Higher Education who has fully supported the research activities in the financing of the Young Research scheme in 2018.

\section{References}

1. D. R. Tobergte and S. Curtis, "Penerapan Sistem Listrik PLN Prabayar Dengan 
Penggunaan Dan Pengoprasian KWH Meter Prabayar Secara IT Dalam E-payment Sistem Pulsa Listrik," J. Chem. Inf. Model., vol. 53, no. 9, pp. 1689-1699, 2013.

2. B. Santoso, I. W. Mustika, and S. S. Kusumawardani, "Pemodelan Monitoring Pethenian Dan Penghematan Energi Listrik Dengan Teknologi Jaringan Sensor Nirkabel," Semin. Nas. Teknol. Inf. dan Komun., vol. 2014, no. Sentika, pp. 20899813, 2014.

3. I. F. Muhammad, M. Abdurohman, and A. Herutomo, "Implementasi Smart Metering Menggunakan Internet Of Things Dengan Transport Protocol Web Socket Berbasis OpenMTC di Universitas Telkom," e-Proceeding Eng., vol. 4, no. 1, pp. 1075-1082, 2017.

4. M. M. Rahman, Noor-E-Jannat, M. O. Islam, and M. S. Salakin, "Arduino and GSM based smart energy meter for advanced metering and billing system," 2 nd Int. Conf. Electr. Eng. Inf. Commun. Technol. iCEEiCT 2015, no. May, pp. 21-23, 2015.

5. R. R. A. Siregar, N. Wardana, and Luqman, "Sistem Monitoring Kinerja Panel Listrik Tenaga Surya Menggunakan Arduino Uno," JETri J. Ilm. Tek. Elektro, vol. 14, no. 2, pp. 81-100, 2017.

6. P. Studi and T. Informatika, "Perancangan Alat Monitoring Arus KWH ( Kilo Watt Hours ) Meter Tiga Phasa Dengan Memanfaatkan Mikrokontroler Arduino dan Sms Gateway Berbasis Web," pp. 1-8.

7. D. Risqiwati, "Rancang Bangun Sistem Monitoring Listrik Prabayar dengan Menggunakan Arduino Uno," Kinetik, vol. 1, no. 2, pp. 47-54, 2016.

8. R. R. A. Siregar, R. Raymond, and R. Arianto, "Model Sistem Telemetri Untuk Monitoring Tandon Air Pada Daerah Kekurangan Air Bersih," pp. 8-15, 2016.

9. D. E. Paul, "Smart Energy Meter Using Android Application And Gsm Network," Int. J. Eng. Comput. Sci., vol. 5, no. 16058, pp. 16058-16063, 2016.

10. K. Hutoro, A. Soeprijanto, O. Penangsang, J. T. Elektro, and F. T. Industri, "Desain Smart Meter Untuk Memantau Dan Identifikasi Pethenian Energi Listrik Pada Sektor Rumah Tangga Menggunakan Backpropagation Neural Network," pp. 1-6.

11. D. D. Prihartomo, R. D. Nyoto, and A. S. Sukamto, "Rancang Bangun Aplikasi Pencatatan Pethenian KWH ( Kilo Watt Hour ) Listrik Digital Menggunakan NFC ( Near Field Communication ) Sebagai Komunikasi Perangkat Pada Platform Android," pp. 1-5.

12. L. Ciabattoni, M. Grisostomi, G. Ippoliti, D. Proietti Pagnotta, G. Foresi, and S. Longhi, "Residential energy monitoring and management based on fuzzy logic," 2015 IEEE Int. Conf. Consum. Electron., no. 2, pp. 536-539, 2015.

13. J. Surya and R. Perumalraja, "a Real-Time Iot Implementation for Efficient Energy Consumption," Int. Res. J. Eng. Technol., vol. 4, no. 6, pp. 1525-1528, 2017.

14. A. Mulyana, T. A. Riza, D. N. Ramadan, M. D. Falih, U. Telkom, and T. Buahbatu, "Sistem Pengisian Pulsa Pada Kwh Meter Prabayar Menggunakan Ponsel Pulse Filling System on Prepaid Electrical Energi," pp. 560-569, 2017. 